\title{
Vulnerability assessment survey of oil and gas facilities to climate-driven sea level rises and storm surges on the west coast of Trinidad
}

\author{
B. Singh ${ }^{1}$, A. El Fouladi ${ }^{1} \&$ K. Ramnath ${ }^{2}$ \\ ${ }^{1}$ Département de Géographie, Université de Montréal, Montréal, Canada \\ ${ }^{2}$ PETROTRIN, Trinidad and Tobago
}

\begin{abstract}
Greenhouse gas (GHG) climate change/global warming is one of the most pressing environmental concerns today. Small Island States, such as Trinidad and Tobago, are highly vulnerable to climate change because of their small size and low elevation, as in the case of this study, which increases their sensitivity to climate change and limits their ability to adapt. In fact, the adaptive capacity of human systems is generally low in Small Island States, and vulnerability generally high. The Petroleum Company of Trinidad and Tobago (PETROTRIN) recently conducted a detailed vulnerability assessment survey and storm surge simulation through modelling for the west coast of Trinidad stretching from Vessigny River in the North to Cap-de-Ville in the South along the Gulf of Paria. This survey was undertaken so as to identify the impacts of climate driven, sea level rises and extreme storm surge events on Petrotrin's and Trinmar's infrastructure and operations. The methodology used to conduct this vulnerability assessment survey involved coupling A-OGCM (AtmosphereOcean General Circulation) model simulations of future sea level rises and TAOS (Total Arbiter of Storms) estimates of storm surges to a GIS-based inundation and erosion scheme so as to estimate land loss and infrastructure facilities at risk from inundation and erosion. The results of the study show that field installations in Petrotrin at Guapo, such as access roads, pipelines, storage tanks and even pump jacks and the offshore operations of Trinmar including offshore platforms, jetties and harbours and administrative buildings would be at severe risk of inundation and erosion deriving from sea level rises and storm surge events.
\end{abstract}

Keywords: climate change, sea level rise, storm surges, impacts and adaptation, coastal zone, Trinidad and Tobago. 


\section{Introduction}

Greenhouse gas (GHG) climate change/global warming is one of the most pressing environmental concerns today. The IPCC's (Intergovernmental Panel on Climate Change) third (TAR: IPCC [4]) and fourth (AR4: IPCC [3]) assessment reports claim that there is very strong evidence that most of the warming observed over the last 50 years or so is attributable to human activities. Furthermore, Small Island States are highly vulnerable to climate change because of their small size and low elevation, as in the case of this study, which increases their sensitivity to climate change and limits their ability to adapt. In fact, both the TAR and AR4 claim that the adaptive capacity of human systems is generally low in Small Island States, and vulnerability generally high. Small Island States, such as Trinidad and Tobago, are therefore likely to be among the countries most seriously affected by climate change and its impacts. Among the most important consequences of climate change, especially for small islands, are sea level rises and storm surge events. They can severely impact upon coastal waters and coastal infrastructures, such as ports and harbours, pumping wells, gathering stations, pipelines, access roads and bridges and buildings, as well as offshore platforms and jetties of oil and gas companies such as PETROTRIN, well into the future.

\section{Methods}

This section deals with the methodologies used to: 1) derive the sea level and storm surge scenarios; 2) construct the Digital Elevation Model (DEM) of the study area so as to calculate the inundation and erosion rates from sea level rises and storm surges.

\subsection{Sea level rise and storm surge}

Scenarios of future climate sea levels on a decadal basis, covering the period 1911-1971, are extracted from the most recent outputs of two coupled atmosphere-ocean general circulation models (A-OGCM'S), namely the Canadian (CGCM2) and British (HadCM3) models. However, these simulations provide a future sea level rise, based solely on thermal expansion, of roughly $25 \mathrm{~cm}$ in the near term (2031), of about $34 \mathrm{~cm}$ in the medium term (2051) and of approximately $51 \mathrm{~cm}$ in the long term (2071) (Singh and El Fouladi [6]).

However, other factors, such as the melting of mountain and sub-polar glaciers and the Greenland and Antarctic ice caps may further contribute to eustatic sea level rises, causing these estimates, based solely on thermal expansion, to more than double (IPCC [4]). Furthermore, crustal land movements that seem to be significant in the Gulf of Paria near the Vessigny-Cap-de-Ville study area may further contribute to a relative sea level rise, causing it to even exceed the rate of a eustatic sea level rise (Singh [8]; El Fouladi [2]). 
The extreme storm surge events are superimposed on the simulated sea level scenarios for the 2031, 2051 and 2071 time periods. Storm surge height simulations are complex and require complex models and data that are time-consuming and have a very high cost. However, empirical values of storm surge heights for the category of storms to be used (moderate: $2 \mathrm{~m}$ and extreme: $5 \mathrm{~m}$ ) in this study can be derived from other studies for similar areas to the study area (such as the TAOS model for the Caribbean).

We therefore adjusted the minimum $(2 \mathrm{~m})$ and maximum $(5 \mathrm{~m})$ storm surges to the sea level rise for these time periods and thereafter, through a GIS-based simulation so as to locate the intersection of the future storm surge heights with the DEM and thus determine the land areas inundated (Singh and El Fouladi [6]).

However, for the offshore platforms, we simply created two generalized storm surge scenarios by superimposing the minimum storm surge $(2 \mathrm{~m})$ and the maximum storm surge $(5 \mathrm{~m})$ on the average sea level derived from CGCM2 and HadCM3 and averaged over the 2031-2071 time period.

\subsubsection{Digital Elevation Model (DEM)}

In order to undertake the simulation of the impacts of the mean sea level rise on the Vessigny-Cap-de-Ville study area, a series of field studies were conducted during October 2006, so as to collect all pertinent data and information required to construct a DEM of the region.

All the Altimetric data to be used in the vulnerability study of the Vessigny-Cap-de-Ville study area are derived from first order photogrammetric restitutions of the relevant aerial photographs whose scale is greater than $1 / 14,500$. This allows for a high level of precision and a relatively high density of points, which could not have been obtained by conventional field survey methods, given the inaccessibility of the terrain in certain parts of the Vessigny-Cap-de-Ville study area. This, for all intents and purposes, will also greatly facilitate the construction of the DEM for the project.

Both the contour heights and their attributes and the spot heights $(50 \times 50 \mathrm{~m})$ covering the entire Vessigny-Cap-de-Ville study area and surrounding land and sea areas, were obtained in numeric format from the Lands and Surveys Division. The total number of spot height points exceeded 15,000.

On account of the extremely indented topography in certain locations within the Vessigny-Cap-de-Ville study area and the coarse resolution of the Lands and Surveys data $(50 \mathrm{~m} \times 50 \mathrm{~m})$, we resorted to the services of L \& S Surveying Services Limited to provide us with a further number of control points that we then used to augment the density of our spot heights data, using conventional surveying and our Total System equipment, for sensitive locations within the Vessigny-Cap-de-Ville study area. The methodology used and the results provided by L \& S Surveying Services Limited are provided in detail in Singh and El Fouladi [6].

A database is then created in which a layer corresponding to the topographic elements, a layer relating to land use and a layer concerning ecosystems and infrastructure facilities, including refinery, tank farms, pipelines, administrative and industrial buildings, access roads and port and harbour are stacked. The 
DEM is then created and this provides the platform upon which future sea level rises and storm surge intrusions are superimposed according to the scenarios of sea level rises (CGCM2 and HadCM3) and storm surges for the three chosen future time periods, namely 2031, 2051 and 2071. The DEM is a virtual representation of the topography, which allows for the analysis and visualisation of the spatial behaviour and the evolution of the various physical and land use phenomena. In this study the DEM allows for the analysis of intrusions deriving from sea level rises and storm surges according to the different scenarios of future sea levels and wind-driven surges in the Gulf of Paria.

For the study, the spot heights data had to be pre-treated and then interpolated so as to attribute an elevation to each point of the study zone using the IDRISI GIS software (Singh El Fouladi [6]). Once the database on elevations for the study area was created, we used the Interpol module of IDRISI to create the DEM of the Vessigny-Cap-de-Ville quadrant along the Gulf of Paria on the west coast of Trinidad (Singh and El Fouladi [6]).

The methodology followed consists of, firstly, the creation of the DEM and of the extraction, using the appropriate modules of the IDRISI GIS software, of the regions and land uses affected by future sea level rises. These extractions for the three future time periods and based on the A-OGCM simulations of sea level rises and the hypothetical storm surges, are then used as the bases upon which further physiographic layers of simulations, namely topography, land use and ecosystems and infrastructure facilities are superimposed.

\subsubsection{Inundation and erosion rates from sea level rises and storm surges}

Thereafter, we used the classification and the utilisation of logical and arithmetic capabilities of IDRISI so as to create the different simulation layers corresponding to the six scenarios of sea level rises, namely three each for the CGCM1 and HadCM3 A-OGCM scenarios for the time periods 2031, 2051 and 2071 , each augmented by the chosen storm surge scenarios, namely $2 \mathrm{~m}$ and $5 \mathrm{~m}$.

Afterwards, buffers are applied to each of these six layers plus storm surges so as to integrate the cumulative effects of inundation and erosion according to the Bruun Rule for the relevant gently-sloping coastlines of the Vessigny-Capde-Ville study area, as well as the beach fronts at Vessigny, Guapo bay and Irois bay (Bruun and Schwartz [1]). As for the parts of the coastline that are protected by hard structures, such as the Point Fortin harbour, we simply only used the rate of inundation as prescribed by each of the A-OGCMs (Singh and El Fouladi [7]).

These sea level rise and storm surge scenario layers were then judiciously juxtaposed to the DEM so as to geographically locate the eventual zones of ocean intrusions in the Vessigny-Cap-de-Ville study site.

Different superpositions, based on the same principles, were then applied to the other GIS layers, relating to topography, land use and ecosystems and infrastructure facilities, so as to graphically visualize the effects of sea level rises on the various land use systems within the Vessigny-Cap-de-Ville study area.

The total study area comprises $88 \mathrm{~km}^{2}$ (Singh and El Fouladi [6]). This total surface area was covered by a matrix grid consisting of 14,570 grid points in which each pixel had an area of $6.25 \mathrm{~m}^{2}$. In addition, there are 356 control points 
and a further 2,100 points were derived from interpolations from contours, where there were data gaps. This allowed us to create vulnerability maps at the $1 / 10.000$ scale. A recent satellite image of the study area was obtained and this was draped over the DEM to derive land cover and use (Singh and El Fouladi [6]).

Finally, based on these various simulations, statistical data are then extracted so as to tabularize land and infrastructure losses, including oil refining and marketing infrastructure facilities and, to a limited extent, ecosystem losses due to rising sea levels and storm surges for the Vessigny-Cap-de-Ville study area.

\section{Results}

Based on the sea level rise scenarios for the CGCM2 and HadCM3 climate models, and the storm surge levels (Singh and El Fouladi [6]), and applying them to the DEM, we then derive the areas of coastland likely to be inundated in the vicinity of the Vessigny-Cap-de-Ville quadrant along the Gulf of Paria on the west coast of Trinidad.

For the purposes of brevity, we present only two maps of coastal inundation and erosion for 2051, one each for the CGCM2 (Figure 1) and HadCM3 (Figure 2) scenarios. In addition we present results for land uses at risk of inundation and erosion from sea level rises and minimum (Table 1) and maximum (Table 2) storm surges for all three time periods (2031, 2051 and 2071) for the Vessigny-Cap-de-Ville quadrant along the Gulf of Paria on the west coast of Trinidad. Due to the lack of space, discussion is focussed on the 2051 period.

\subsection{Mapping sea level rises and storm surge impacts: CGCM2}

At first, examining land inundation on account of the sea level rise for 2051, it is evident that the low-lying parts of the coastline, such as at Vessigny beach, Vance River and at Guapo where major field operations of Petrotrin, including access roads, pipelines, storage tanks and collector ponds are located, will be inundated (Figure 1). Total land loss due to inundation by 2051 amounts to 5.65 hectares. The greatest land loss categories belong to landuse categories: broken forest and scattered forests, agriculture and residential (Figure 1 and Table 1).

For 2051, when sea level rise erosion effects are incorporated, the amount of land loss increases to 218.23 hectares. The landuse categories of grassland, residential, scattered forests, agriculture and residential and grassland and scrub suffer the greatest losses (Figure 1 and Table 1).

When the minimum storm surge $(2 \mathrm{~m})$ is superimposed on sea level rise, a good part of Point Fortin where Trinmar operations are located is flooded. Land losses on account of the minimum storm surge $(2 \mathrm{~m})$ effect amount to 156.8 hectares, thereby causing total land loss due to inundation erosion and minimum storm surge to total 380.68 hectares by 2051. Again the landuse categories affected by the minimum storm surge are industrial, residential and agriculture (Figure 1 and Table 1). 


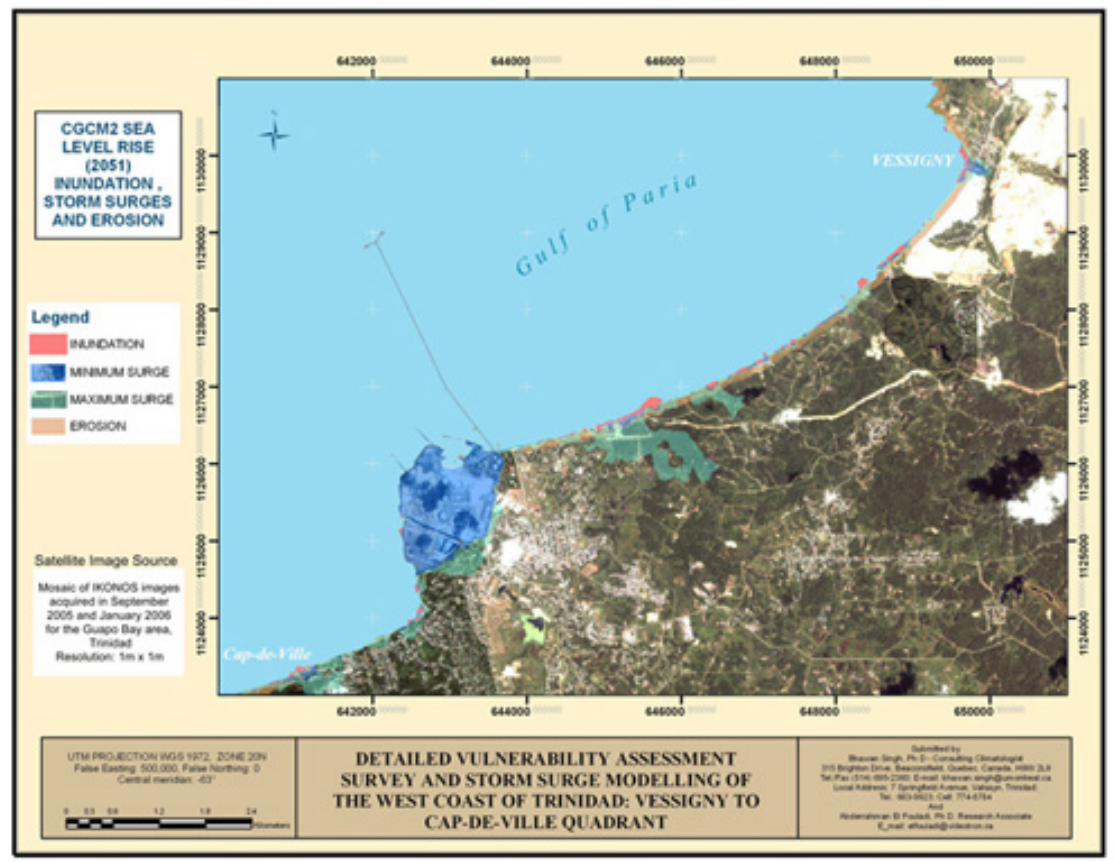

Figure 1: $\quad$ Sea level rise impacts CGCM2 (2051).

Table 1: Land loss through sea level rise plus minimum storm surge combined with erosion: CGCM2 and HadCM3.

\begin{tabular}{|c|cc|cc|cc|}
\hline \multirow{2}{*}{ Landuse } & $\begin{array}{c}\text { CGCM2 } \\
2031\end{array}$ & $\begin{array}{c}\text { HadCM3 } \\
2031\end{array}$ & $\begin{array}{c}\text { CGCM2 } \\
2051\end{array}$ & $\begin{array}{c}\text { HadCM3 } \\
2051\end{array}$ & $\begin{array}{c}\text { CGCM2 } \\
2071\end{array}$ & $\begin{array}{c}\text { HadCM3 } \\
2071\end{array}$ \\
\cline { 2 - 8 } & $\begin{array}{c}\text { Area } \\
\text { (ha) }\end{array}$ & $\begin{array}{c}\text { Area } \\
\text { (ha) }\end{array}$ & $\begin{array}{c}\text { Area } \\
\text { (ha) }\end{array}$ & $\begin{array}{c}\text { Area Lost } \\
\text { (ha) }\end{array}$ & $\begin{array}{c}\text { Area } \\
\text { (ha) }\end{array}$ & $\begin{array}{c}\text { Area Lost } \\
\text { (ha) }\end{array}$ \\
\hline Sparse Forest & 0.00 & 0.00 & 0.00 & 0.00 & 0.00 & 0.00 \\
\hline Mangrove & 0.01 & 0.03 & 0.00 & 0.01 & 0.00 & 0.01 \\
\hline Forest & 0.00 & 0.00 & 0.00 & 0.00 & 0.00 & 0.00 \\
\hline Grassland & 0.13 & 0.27 & 0.01 & 0.17 & 0.00 & 0.13 \\
\hline Agricultural & 1.68 & 1.82 & 1.54 & 1.75 & 1.32 & 1.69 \\
\hline Residential & 2.51 & 2.74 & 2.49 & 2.53 & 2.32 & 2.47 \\
\hline Industrial & 4.53 & 3.91 & 152.77 & 4.14 & 153.08 & 3.98 \\
\hline Forest/Agriculture & 0.00 & 0.00 & 0.00 & 0.00 & 0.00 & 0.00 \\
\hline Clear/Broken Forest & 0.00 & 0.00 & 0.00 & 0.00 & 0.00 & 0.00 \\
\hline Broken Forest/Grassland & 0.00 & 0.00 & 0.00 & 0.00 & 0.00 & 0.00 \\
\hline Grassland/Agricultural & 0.00 & 0.00 & 0.00 & 0.00 & 0.00 & 0.00 \\
\hline Clear/Scrub & 0.00 & 0.00 & 0.00 & 0.00 & 0.00 & 0.00 \\
\hline Grassland/Scrub & 0.00 & 0.00 & 0.00 & 0.00 & 0.00 & 0.00 \\
\hline $\begin{array}{c}\text { Total } \\
\text { Inundation+ Erosion }\end{array}$ & 8.86 & 8.77 & 156.80 & 8.60 & 156.72 & 8.28 \\
\hline $\begin{array}{c}\text { (Inundation + Erosion) } \\
\text { + Storm Surge }\end{array}$ & 213.87 & 186.80 & 380.68 & 202.71 & 380.68 & 211.72 \\
\hline
\end{tabular}


However, when the maximum storm surge $(5 \mathrm{~m})$ is superimposed on sea level rise the effects are catastrophic for the town of Point Fortin where Trinmar operations are located and for the Guapo area where several field installations of Petrotrin, including access roads, pump jacks, pipelines, storage tanks and oil capture ponds are located. Land losses on account of the maximum storm surge (5m) effect amount to 275.3 hectares, thereby causing total land loss due to inundation erosion and maximum storm surge to total 499.18 hectares by 2051 . Landuse categories most impacted upon by the maximum storm surge are again industrial, residential, grassland and mangrove (Figure 1 and Table 2).

Table 2: $\quad$ Land loss through sea level rise plus maximum storm surge combined with erosion: CGCM2 and HadCM3.

\begin{tabular}{|c|cc|cc|cc|}
\hline \multirow{2}{*}{ Landuse } & $\begin{array}{c}\text { CGCM2 } \\
2031\end{array}$ & $\begin{array}{c}\text { HadCM3 } \\
2031\end{array}$ & $\begin{array}{c}\text { CGCM2 } \\
2051\end{array}$ & $\begin{array}{c}\text { HadCM3 } \\
2051\end{array}$ & $\begin{array}{c}\text { CGCM2 } \\
2071\end{array}$ & $\begin{array}{c}\text { HadCM3 } \\
2071\end{array}$ \\
\cline { 2 - 8 } & $\begin{array}{c}\text { Area } \\
\text { (ha) }\end{array}$ & $\begin{array}{c}\text { Area } \\
\text { (ha) }\end{array}$ & $\begin{array}{c}\text { Area } \\
\text { (ha) }\end{array}$ & $\begin{array}{c}\text { Area Lost } \\
\text { (ha) }\end{array}$ & $\begin{array}{c}\text { Area } \\
\text { (ha) }\end{array}$ & $\begin{array}{c}\text { Area Lost } \\
\text { (ha) }\end{array}$ \\
\hline Sparse Forest & 0.56 & 0.45 & 0.65 & 0.54 & 43.42 & 0.56 \\
\hline Mangrove & 18.70 & 17.62 & 24.83 & 18.23 & 26.75 & 18.49 \\
\hline Forest & 0.00 & 0.00 & 0.00 & 0.00 & 0.54 & 0.00 \\
\hline Grassland & 24.20 & 23.53 & 24.21 & 23.84 & 23.35 & 24.13 \\
\hline Agricultural & 2.57 & 2.96 & 2.20 & 2.74 & 1.80 & 2.58 \\
\hline Residential & 42.11 & 40.78 & 49.26 & 41.24 & 52.28 & 41.47 \\
\hline Industrial & 159.96 & 160.00 & 160.03 & 160.00 & 164.75 & 159.97 \\
\hline Forest/Agriculture & 8.21 & 8.35 & 8.23 & 8.20 & 8.87 & 8.20 \\
\hline Clear/Broken Forest & 0.00 & 0.00 & 0.01 & 0.00 & 0.15 & 0.00 \\
\hline Broken Forest/Grassland & 8.50 & 4.18 & 12.13 & 4.83 & 16.27 & 8.06 \\
\hline Grassland/Agricultural & 0.00 & 0.00 & 0.00 & 0.00 & 0.00 & 0.00 \\
\hline $\begin{array}{c}\text { Clear/Scrub } \\
\text { Grassland/Scrub }\end{array}$ & 0.00 & 0.00 & 0.00 & 0.00 & 0.00 & 0.00 \\
\hline $\begin{array}{c}\text { Total } \\
\text { Inundation+ Erosion }\end{array}$ & 264.80 & 256.05 & 275.30 & 259.76 & 354.37 & 263.47 \\
\hline $\begin{array}{c}\text { (Inundation + Erosion) } \\
\text { + Storm Surge }\end{array}$ & 469.81 & 436.08 & 499.18 & 453.86 & 616.86 & 466.91 \\
\hline
\end{tabular}

\subsubsection{Mapping sea level rises and storm surge impacts: HadCM3}

Secondly, using the HadCM3 scenario, we now determine inundation and land loss on account of sea level rises and minimum and maximum storm surges for the year 2051 for the Vessigny-Cap-de-Ville quadrant along the Gulf of Paria on the west coast of Trinidad.

When examining land inundation on account of the sea level rise for 2051 according to HadCM3, it is again evident that the low-lying parts of almost the entire coastline between Vessigny beach and Cap-de-Ville will be at the risk of inundation. This is critical for the coastline near Guapo where major field operations of Petrotrin, including access roads, pipelines, storage tanks and collector ponds are located (Figure 2). Total land loss due to inundation by 2051 amounts to 4.28 hectares. Again, the greatest land loss belongs mainly to the landuse categories of scattered forests, agriculture and residential, and also to broken/sparse forest, grassland agriculture and residential (Figure 2 and Table 1). 
Furthermore, by 2051, when sea level rise erosion effects are incorporated, the amount of land loss increases to 189.83 hectares. Again, mainly the landuse categories of scattered forests, agriculture and residential, grassland, residential, and grassland and scrub suffer the greatest losses of land area (Figure 2 and Table 1).

When the minimum storm surge $(2 \mathrm{~m})$ is superimposed on the sea level rise for 2051 according to HadCM3, some parts of Point Fortin where Trinmar operations are located are flooded. Total land loss due to inundation erosion and minimum storm surge amounts to 202.71 hectares by 2051. Again the landuse categories affected by the minimum storm surge are industrial, mainly, and to a lesser extent, agriculture and residential (Figure 2 and Table 1).

However, when the maximum storm surge $(5 \mathrm{~m})$ is superimposed on the sea level rise the effects become catastrophic for the town of Point Fortin where Trinmar operations are located and for the Guapo area where several field installations of Petrotrin, including access roads, pump jacks, pipelines, storage tanks and oil capture ponds are located. Furthermore, total land loss due to inundation erosion and maximum storm surge totals 453.86 hectares by 2051 according to HadsCM3. Landuse categories most impacted upon by the maximum storm surge are again mainly industrial, mangrove, grassland and residential (Figure 2 and Table 2).

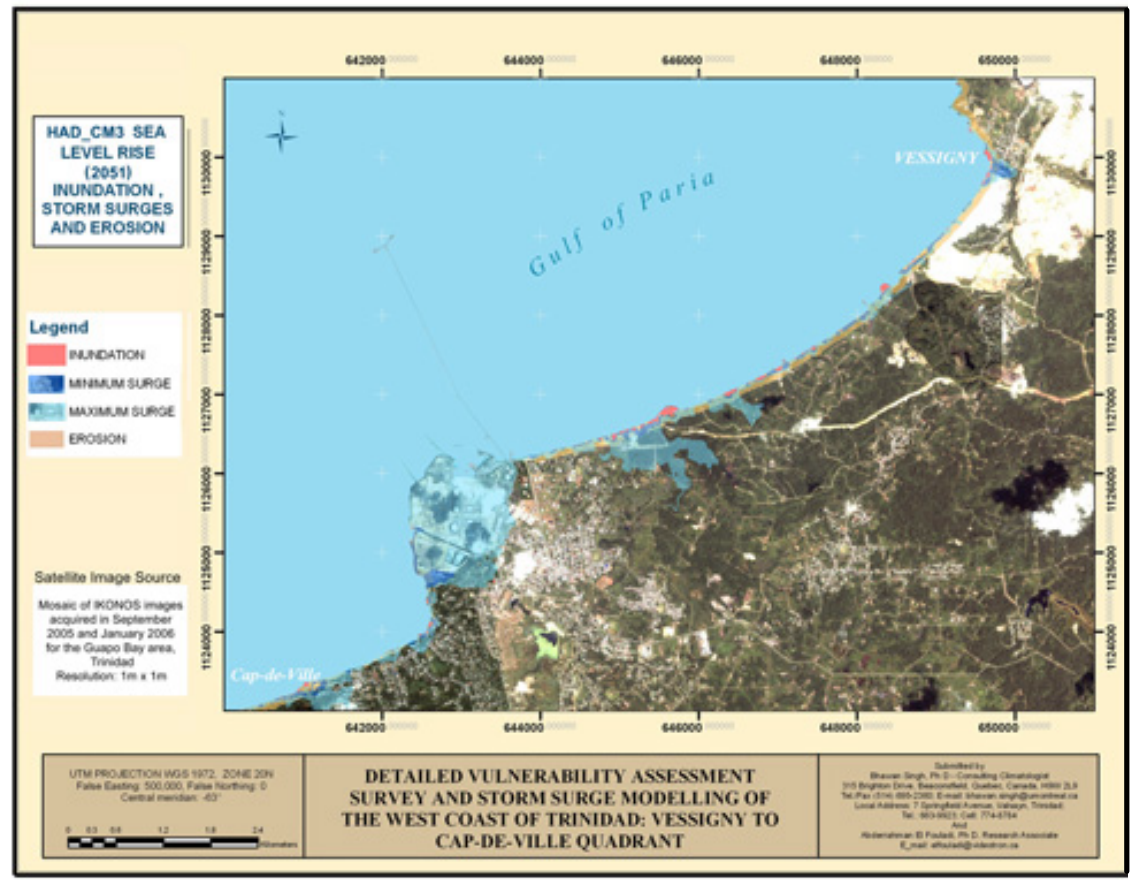

Figure 2: $\quad$ Sea level rise impacts HadCM3 (2051). 


\subsubsection{Mapping sea level rise and storm surge impacts on offshore platforms}

The offshore well platforms of Trinmar in the Gulf of Paria off Point Fortin are now considered. However, since we are not dealing with land loss, only the minimum $(2 \mathrm{~m})$ and maximum $(5 \mathrm{~m})$ storm surges, averaged between sea level rises for CGCM2 and HadCM3 and over the 2031-2071 period, are considered. These platforms, numbering about 30 , consist of drilling platforms with adjacent bloc stations, drilling platforms without adjacent bloc stations, compressor platforms and bloc stations (see Singh and El Fouladi [6]).

Two general classes of platforms are used for this study. In the first group are platforms whose elevations are higher: top deck 27 feet 9 inches and lower deck 12 feet 6 inches. These would include platform numbers 3-9. In the second group of platforms, the elevations are lower: top deck 20 feet 6 inches and lower deck 8 feet 0 inches. These would include platform numbers $9-11$ and 13 (see Singh and El Fouladi [6]). In this study we selected platform number 20 that we visited and for which we had images and measurements. This is a drilling platform with an adjacent bloc station belonging to the first category: top deck 27 feet 9 inches and lower deck 12 feet 6 inches.

When applying the minimum $(2 \mathrm{~m})$ and maximum storm surge $(5 \mathrm{~m})$, we see that for the higher platforms, the minimum storm surge would inundate the lower deck and the maximum storm surge would reach close to the upper deck (see Singh and El Fouladi [6]). However, when applying the minimum $(2 \mathrm{~m})$ and maximum storm surge $(5 \mathrm{~m})$, for the lower platforms, the minimum storm surge would inundate the lower deck and maximum storm surge would inundate both the lower and upper decks (see Singh and El Fouladi [6]).

\section{Conclusions}

Based on the results of the preceding sections then, it is evident that future sea level rises, according to the CGCM2 and the HadCM3 scenarios, and extreme weather events, considering a category 2 hurricane and a minimum $(2 \mathrm{~m})$ storm surge and a category 5 hurricane and a maximum $(5 \mathrm{~m})$ storm surge, would cause moderate to severe land loss in the Vessigny to Cap-de-Ville quadrant along the Gulf of Paria in the west coast of Trinidad. The CGCM2 scenario produces greater land losses, because it projects a higher future sea level rise than the HadCM3 scenario, which is more conservative. However recent reports show that climate models are grossly underestimating current levels of sea level rises and this would translate into much higher sea levels in the future (Rahmstorf [5]). The IPCC suite of climate models project sea levels to rise by 0.09 to $0.88 \mathrm{~m}$ by 2100 (IPCC [4]). However, Rahmstorf claims that based on his analyses these figures should be much higher and would be, according to his calculations, 0.5 to $1.4 \mathrm{~m}$ by 2100 (Rahmstorf [5]).

Also, surprisingly, it would appear, according to our simulations, that land area loss is more significant when the effects of erosion are ignored. This is due to the fact that when erosion effects are integrated in the simulations steep cliffs are created in the evolving DEM, which limits the intrusion of the storm surges into the interior of the land. 
These land losses, especially when considering the sea level rise and maximum storm surge, are most significant at Point Fortin where Trinmar field and administrative operations are located and at Guapo Bay, where major field installations of Petrotrin are to be found.

Furthermore, when considering the offshore oil well platforms of Trinmar it would appear that the lower decks of most platforms would be inundated by the minimum storm surge and that both the lower and upper decks of the lower platforms would be inundated by the maximum storm surge. However, apart from inundation, wind and wave attack may cause further damage to these offshore platforms.

\section{References}

[1] Bruun, P.T. \& Schwartz, M.L. Analytical predictions of beach profile change in response to a sea level rise. Z. Geomorphol., N.F. Suppl., 57:33$50,1985$.

[2] El Fouladi, A. Hausse du Niveau Moyen Relatif de la Mer (À Trinidad, Caraïbes) : Évidence, Causes Probables, et Évaluation. Thèse de Doctorat, Département de géographie, Université de Montréal, 202 p, 2006.

[3] IPCC, 2007: Climate Change 2007: Impacts, Adaptation and Vulnerability. Contribution of Working Group II to the Fourth Assessment Report of the Intergovernmental Panel on Climate Change, M.L. Parry, O.F. Canziani, J.P. Palutikof, P.J. van der Linden and C.E. Hanson, Eds., Cambridge University Press, Cambridge, UK, 976pp, 2007.

[4] Intergovernmental Panel on Climate Change (IPCC). Climate Change 2001: Impacts, Adaptation, and Vulnerability. Contribution of Working Group 11 to the Third Assessment Report of the Intergovernmental Panel on Climate Change (McCarthy, J.J., O.F. Canziani, N.A. Leary, D.J. Dokken, and K.S. White (eds)). Cambridge University Press, Cambridge, United Kingdom and New York, N.Y., USA, 1032 pp, 2001.

[5] Rahmstorf, S. Sea Level Rise Underestimated. Science Express, 2007.

[6] Singh, B. \& El Fouladi, A. Detailed Vulnerability Assessment Survey and Storm Surge Modelling of the West Coast of Trinidad: Vessigny to Cap-deVille Quadrant. PETROTRIN/HSE Report, 462 p, 2007.

[7] Singh, B. \& El Fouladi, A. Vulnerability Assessment Study for the Relocation of PETROTRIN TRINMAR'S Operations Marine Base to the Mt. Pellier Estate. Final Report, Climate Change Institute, Health, Safety and Quality Division: PETROTRIN, Pointe-è-Pierre, Trinidad, August, 179 p, 2004.

[8] Singh, B. Climate-induced global changes in the southern Caribbean: Trinidad and Tobago, Global Planetary Changes, 15, pp. 93-111, 1997. 